\title{
Effect of Sulfide on Carbon Steel Corrosion in Anaerobic Near-Neutral pH Saline Solutions
}

\author{
B.W.A. Sherar, ${ }^{\ddagger *}$ P.G. Keech, ${ }^{* \star}$ J.J. Noël, ${ }^{* * *}$ R.G. Worthingham, ${ }^{* * * *}$ and D.W. Shoesmith ${ }^{\star * *}$
}

\section{ABSTRACT}

Severe corrosion damage may occur when gas transmission pipelines are exposed, at disbonded coating locations, to trapped waters containing sulfide. This scenario has been investigated in long-term anaerobic experiments in which corrosion was followed by measurement of corrosion potentials and relative corrosion rates obtained from linear polarization resistance measurements. The properties and composition of the corrosion product deposits formed were determined using scanning electron microscopy, energy-dispersive $x$-ray analysis, and Raman spectroscopy. Under anaerobic conditions, corrosion rates were lower for freshly polished steel than for precorroded carbon steel exposed to sulfide, suggesting preoxidization of the steel surface prevents passivation in the presence of sulfide. Under these last conditions, a non-protective layer of mackinawite forms on the surface and magnetite/maghemite are chemically converted to sulfide and sulfur, leading to a slow increase in corrosion rate.

KEY WORDS: carbon steel, corrosion potential, corrosion rate, microbially induced corrosion, pipelines, scanning electron microscopy, sulfur

Submitted for publication: March 13, 2012. Revised and accepted: May 28, 2012. Preprint available online: July 11, 2012, http://dx.doi.org/10.5006/0687.

‡ Corresponding author. E-mail: bsherar@blade-energy.com.

* Blade Energy Partners, Ltd., 16285 Park 10 Place, Suite 600, Houston, TX 77084.

** Nucear Waste Management Organization, 22 St. Clair Avenue East, Toronto, ON, M4T 2S3.

${ }^{* * *}$ University of Western Ontario, Department of Chemistry, 1151 Richmond Street, London, ON, N6A 5B7.

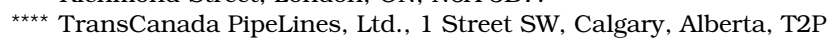
5H1, Canada.

\section{INTRODUCTION}

Gas transmission pipelines are protected by a combination of coatings and cathodic protection (CP). External corrosion of buried pipeline-grade carbon steel occurs when coatings, used to protect the steel, disbond, exposing the steel to groundwater and inhibiting CP. ${ }^{1-2}$ Based primarily on field inspections of coating failure sites ${ }^{1-2}$ TransCanada PipeLines, Ltd. (TCPL, Calgary, Alberta, Canada) has proposed six corrosion scenarios that lead to pipeline damage. ${ }^{1-2}$ One particularly damaging corrosion scenario involves anaerobic corrosion with microbial effects, and occurs in $27 \%$ of all reported coating failure sites. ${ }^{1-2}$

The nature of the corrosion process for carbon steel is influenced significantly by the anionic composition of the trapped water (i.e., the water located underneath the disbonded coating), which contains $\mathrm{Cl}^{-}, \mathrm{HCO}_{3}^{-} / \mathrm{CO}_{3}^{2-}$, and sulfur-containing species of various oxidation states, from $\mathrm{SO}_{4}^{2-}(+6)$ to $\mathrm{HS}^{-}(-2)$. Anaerobic corrosion is associated with a low corrosion rate (CR) (i.e., $<10 \mu \mathrm{m} / \mathrm{y})^{2}$ and the formation of pasty siderite $\left(\mathrm{FeCO}_{3}\right)$ deposits. ${ }^{1}$ However, when microbially induced corrosion (MIC) is observed, trapped waters are found to contain sulfur species, especially sulfides produced by sulfate-reducing bacteria, organisms commonly found in the soil near buried pipelines. Consequently, CR are much higher (between $200 \mu \mathrm{m} / \mathrm{y}$ and $700 \mu \mathrm{m} / \mathrm{y})^{2-3}$ and mackinawite $\left(\mathrm{Fe}_{1+\mathrm{x}} \mathrm{S}\right)$ is a major corrosion product. ${ }^{2,4}$ Should such an anaerobic site turn aerobic, CR become extremely high (i.e., $2 \mu \mathrm{m} / \mathrm{y}$ to $5 \mathrm{~mm} / \mathrm{y})^{2}$ because iron sulfides oxidize to form $\mathrm{Fe}^{\mathrm{III}}$ oxides and sulfur or sulfate. ${ }^{1}$ 
TABLE 1

Corrosion Experiments Performed and the Experimental Conditions Used

\begin{tabular}{cccc}
\hline CE & $\begin{array}{c}\text { Steel } \\
\text { Grade }\end{array}$ & $\begin{array}{c}\text { Preconditioning } \\
\text { Solution }^{(\mathrm{A})}\end{array}$ & $\begin{array}{c}\text { Exposure } \\
\text { Solution }\end{array}$ \\
\hline 1 & A516 Gr 70 & - & Concentrated $^{(\mathrm{B})}$ \\
2 & $\mathrm{X} 65$ & - & Dilute $^{(\mathrm{C})}$ \\
3 & A516 Gr 70 & $\mathrm{E}=-750 \mathrm{mV} ;$ & Concentrated $^{(\mathrm{B})}$ \\
& & $60^{\circ} \mathrm{C}$ & \\
\hline
\end{tabular}

(A) Preconditioning solution: $1 \mathrm{~mol} \mathrm{~L}-1 \mathrm{NaHCO}_{3} / \mathrm{Na}_{2} \mathrm{CO}_{3}$.

(B) Concentrated solution: $0.2 \mathrm{~mol} \mathrm{~L}^{-1} \mathrm{NaHCO}_{3}+0.1 \mathrm{~mol} \mathrm{~L}^{-1} \mathrm{NaCl}+$ $0.1 \mathrm{~mol} \mathrm{~L}^{-1} \mathrm{Na}_{2} \mathrm{SO}_{4}$.

(C) Dilute solution: $5.2 \times 10^{-3} \mathrm{~mol} \mathrm{~L}^{-1} \mathrm{NaHCO}_{3}+6.2 \times 10^{-3} \mathrm{~mol} \mathrm{~L}^{-1}$ $\mathrm{Na}_{2} \mathrm{CO}_{3}+0.6 \times 10^{-3} \mathrm{~mol} \mathrm{~L}^{-1} \mathrm{NaCl}+0.5 \times 10^{-3} \mathrm{~mol} \mathrm{~L}^{-1} \mathrm{Na}_{2} \mathrm{SO}_{4}+$ $0.1 \mathrm{~mol} \mathrm{~L}^{-1} \mathrm{NaClO}_{4}$.

In an attempt to mimic the relevant trapped water chemistry while avoiding the use of bacteria, we have used sodium sulfide $\left(\mathrm{Na}_{2} \mathrm{~S} \cdot 9 \mathrm{H}_{2} \mathrm{O}\right)$ as the source of $\mathrm{HS}^{-}$. Comparison of results from this type of study to published literature ${ }^{3,5}$ and field data ${ }^{1-2}$ will aid the development of a better understanding of the interactions of steel with sulfide under various redox conditions. In a previous paper, ${ }^{6}$ we compared the morphology and composition of the deposits formed on carbon steel by inorganic sulfide to those formed by sulfide produced microbially. Although the film morphologies were different, Raman analyses confirmed that both inorganic and biological $\mathrm{HS}^{-}$sources lead to mackinawite film formation. ${ }^{6}$

Following our previously developed methodology, ${ }^{7-9}$ several long-term anaerobic corrosion experiments were performed in solutions containing various sulfide concentrations. The corrosion potential $\left(\mathrm{E}_{\mathrm{CORR}}\right)$ was monitored and relative CR were measured periodically using linear polarization resistance (LPR) measurements. Subsequently, the morphology and composition of the corrosion product deposits were determined using scanning electron microscopy (SEM), energy-dispersive $\mathrm{x}$-ray spectroscopy (EDX), and Raman spectroscopy.

\section{EXPERIMENTAL PROCEDURES}

\section{Materials and Electrode Preparation}

Experiments were performed with either X65 carbon steel (0.07 C; 1.36 Mn; 0.013 P; 0.002 S; 0.26 Si; $0.01 \mathrm{Ni}$; $0.2 \mathrm{Cr}$; $0.011 \mathrm{Al}$ [wt\%]) with a balance of $\mathrm{Fe}$ (provided by TCPL) or A516 Gr 70 carbon steel (0.23 C; $1.11 \mathrm{Mn}$; 0.07 P; 0.10 S; 0.26 Si; $0.01 \mathrm{Cu} ; 0.01 \mathrm{Ni}$; $0.02 \mathrm{Cr} ; 0.004 \mathrm{Mo}$; $0.036 \mathrm{Al}$; $0.019 \mathrm{~V}$; $0.003 \mathrm{O}$ [wt\%]) with a balance of Fe purchased from Unlimited Metals (Longwood, Florida). For corrosion measurements, cubic coupons, 1.0 by 1.0 by $1.0 \mathrm{~cm}$, were cut from metal plates and fitted with a carbon steel welding rod (4 mm diameter) to facilitate connection to external electrochemical equipment. Electrodes and specimens were then encased in a high-performance epoxy resin with only a single face exposed to prevent exposure of the electrical contact to the solution. Prior to each experiment, the exposed face (surface area: $1.0 \mathrm{~cm}^{2}$ ) was polished sequentially on $180,320,600$, and 1200 grit silicon carbide $(\mathrm{SiC})$ paper, and then ultrasonically cleaned for $10 \mathrm{~min}$ in ultrapure deionized water (Millipore ${ }^{\dagger}$,conductivity: $18.2 \mathrm{M} \Omega \cdot \mathrm{cm}$ ) mixed with methanol $\left(\mathrm{CH}_{3} \mathrm{OH}\right)$ at a ratio of $1: 1$ to remove organics, and finally ultrasonically cleaned in deaerated, deionized water.

\section{Solutions}

Three experiments were performed and designated CE1, CE2, and CE3. A516Gr70 steel specimens were used in experiments CE1 and CE3, in which they were exposed to a concentrated simulated groundwater, and X65 steel in experiment CE2, which used a dilute simulated groundwater. In general, the ion concentrations in the dilute solution were comparable to those encountered in natural ground waters, ${ }^{10}$ though perchlorate was added to increase the conductivity. This anion is not expected to have any significant influence on corrosion behavior. ${ }^{11}$ The compositions of all exposure solutions are given in Table 1, and the composition of the concentrated solution was chosen to allow comparison to previous measurements. ${ }^{7-9,12-14}$ The $\mathrm{pH}$ of all solutions was set to $8.90 \pm 0.05$ with sodium hydroxide $(\mathrm{NaOH})$ prior to beginning the experiment. While high compared to values in the range expected for trapped water (e.g., 5 to 7.3), the choice of this value enables us to compare observed behavior to the results of previous experiments. Also listed in Table 1 is the composition of the preconditioning solution used in CE3.

To maintain anaerobic conditions, CE1 and CE2 were performed in an anoxic chamber in Ar-purged solutions. Anaerobic conditions were maintained in CE3 by continuously purging the electrolyte solutions with ultrahigh-purity Ar.

\section{Electrochemical Cell and Equipment}

Experiments were conducted in a standard threeelectrode glass electrochemical cell. The counter electrode was a $\mathrm{Pt}$ foil and the reference electrode a commercial saturated calomel electrode (SCE; $241 \mathrm{mV}$ vs. standard hydrogen electrode [SHE]). The cell was either housed in a grounded Faraday cage or placed in a grounded anoxic chamber to minimize external noise. Prior to immersion of the steel coupons, the electrolyte solutions were purged for at least $1 \mathrm{~h}$ in ultrahigh-purity Ar to generate anaerobic conditions. Each experiment was performed using either a Solartron $1480^{\dagger}$ multistat or a Solartron $1287^{\dagger}$ potentiostat, running Corrware ${ }^{\dagger}$ software (ver. 2.6 Scribner Associates $^{\dagger}$ ) to control applied potentials and to record current responses.

\footnotetext{
+ Trade name.
} 


\section{Procedures}

The individual corrosion procedures are summarized in Table 2 . This sequence of experiments was designed to investigate the following features:

-influence of $\mathrm{HS}^{-}$after a period of anaerobic corrosion (CE1)

-influence of $\mathrm{HS}^{-}$in dilute groundwater (CE2)

-influence of $\mathrm{HS}^{-}$on anaerobic corrosion after a series of anaerobic-aerobic cycles (CE3)

Figure 1 shows the general potential (E)-time profile used to cathodically clean and precondition the steel samples (CE3 only), ${ }^{7,15}$ and to follow their corrosion behavior. Besides the working electrode used to measure $\mathrm{E}_{\mathrm{CORR}}$ and polarization resistance $\left(\mathrm{R}_{\mathrm{P}}\right)$, additional steel electrodes were exposed to the same conditions and used in subsequent analyses. In stage 1, all electrodes were cathodically cleaned at $-1.3 \mathrm{~V}$ for $1 \mathrm{~min}$ to reduce air-formed surface oxide. The potential then was stepped to $-1.1 \mathrm{~V}$ (Stage 2) to reduce $\mathrm{H}_{2}$ production and allow the surface to be cleared of $\mathrm{H}_{2}$ bubbles while maintaining CP. For CE3, the potential was then stepped to $-750 \mathrm{mV}$ for $50 \mathrm{~h}$ (Stage 3) in the preconditioning solution to anodically form a siderite/magnetite film at room temperature. ${ }^{7,15}$ The electrodes then were removed from the preconditioning cell, rinsed in deaerated, deionized water, and placed in the cell containing the exposure solution. Details of the exposure during CE3 over the period prior to adding $\mathrm{HS}^{-}$have been discussed elsewhere, ${ }^{7-9}$ and involved a series of anaerobic-aerobic cycles lasting 202 days prior to sulfide addition. No preconditioning step was used in CE1 and CE2; the electrodes and additional specimens were cathodically cleaned (stages 1 and 2) in the exposure solution cell prior to switching to open circuit (stage 4, Figure 1).

$\mathrm{E}_{\mathrm{CORR}}$ was monitored continuously through stage 5 , except for brief periods (every $24 \mathrm{~h}$ ) during which LPR measurements were made. LPR measurements were performed by scanning the potential $\pm 10 \mathrm{mV}$ from $\mathrm{E}_{\mathrm{CORR}}$ at a scan rate of $0.1 \mathrm{mV} \mathrm{s}^{-1}$, and required a total of $10 \mathrm{~min}$. Periodically, specimens were removed for surface analysis (stage 5), the details of which are reported below or elsewhere. ${ }^{8}$

\section{Surface Analysis}

Specimens and electrodes removed from solution during, or on completion of, an experiment were analyzed using SEM (using both secondary and backscatter imaging modes), EDX analysis, optical imaging, and Raman spectroscopy. SEM was performed along with EDX to elucidate the morphology of corrosion deposits and their elemental composition using a Hitachi $\mathrm{S} 4500^{\dagger}$ field emission SEM and a primary beam voltage of $10 \mathrm{keV}$. To identify iron oxide/sulfide phases, a Renishaw $2000^{\dagger}$ Raman spectrometer, with a $632.8 \mathrm{~nm}$ laser line and an optical microscope with a 50X magnification objective lens, were used; optical images were also obtained on this instrument. The
TABLE 2

Corrosion Exposure Sequence for Individual Corrosion Experiments

\begin{tabular}{cl}
\hline CE & \multicolumn{1}{c}{ Corrosion Exposure Sequence } \\
\hline 1 & Anaerobic $\rightarrow$ anaerobic $+\mathrm{HS}^{-}$ \\
2 & Anaerobic $+\mathrm{HS}^{-}$ \\
3 & Preconditioned $\rightarrow$ anaerobic $\rightarrow$ aerobic $\rightarrow \ldots \rightarrow$ \\
& anaerobic $+\mathrm{HS}^{-}$ \\
\hline
\end{tabular}

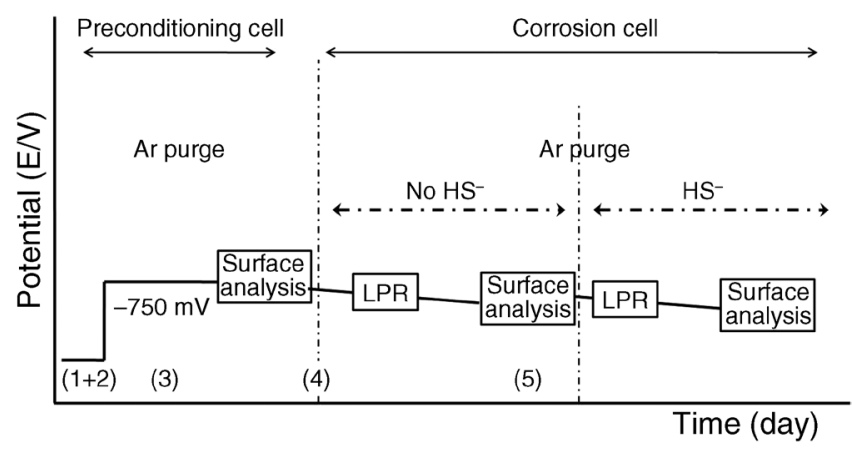

FIGURE 1. General potential (E)-time profile used to prepare electrodes and specimens (including the preconditioning solution used in CE3) and throughout the corrosion experiment. The various stages used for individual experiments are described in the text and in Tables 1 and 2.

TABLE 3

Expected Raman Peak Positions for Various Iron Oxide/Sulfide Phases

\begin{tabular}{lllc}
\hline Compound & $\begin{array}{l}\text { Chemical } \\
\text { Formula }\end{array}$ & \multicolumn{1}{c}{ Raman Shift/cm } & Reference \\
\hline Ferrous sulfate & $\mathrm{FeSO}_{4}$ & 990 & 20 \\
Mackinawite & $\mathrm{Fe}_{1+\times} \mathrm{S}$ & $254,307,318,354$ & 17 \\
Maghemite & $\gamma-\mathrm{Fe}_{2} \mathrm{O}_{3}$ & $358,499,678,710$ & 16 \\
Magnetite & $\mathrm{Fe}_{3} \mathrm{O}_{4}$ & $297,523,666$ & 16 \\
Siderite & $\mathrm{FeCO}_{3}$ & $734,1,089,1,443,1,736$ & 18 \\
Sulfur & $\mathrm{S}^{0}$ & $150,220,475$ & 21 \\
\hline
\end{tabular}

expected Raman peak positions for various Fe oxide/ sulfide phases are summarized in Table $3 .^{16-21}$

\section{RESULTS AND DISCUSSION}

\section{CE1: Effect of Sulfide on Steel Covered by a Thin, Anaerobically Formed Oxide/Carbonate Layer}

In this experiment, sulfide was added to the exposure solution cell after anaerobic corrosion of untreated steel for 35 days. Figure 2 shows the behavior of $\mathrm{E}_{\mathrm{CORR}}$ and $\mathrm{R}_{\mathrm{P}}^{-1}$ (proportional to the CR [assuming uniform corrosion]), over the duration of the experiment. The initial decreases in $\mathrm{E}_{\mathrm{CORR}}$ and $\mathrm{R}_{\mathrm{P}}^{-1}$ indicate the formation of a partially protective corrosion product deposit. Once established, the steady-state $\mathrm{E}_{\mathrm{CORR}}$ value remained low $(-820 \mathrm{mV})$ and $\mathrm{R}_{\mathrm{P}}{ }^{-1}$ remained constant at $\sim 1 \times 10^{-4} \Omega^{-1} \mathrm{~cm}^{-2}$. Similar corrosion behavior was observed previously on an electrode pretreated to 


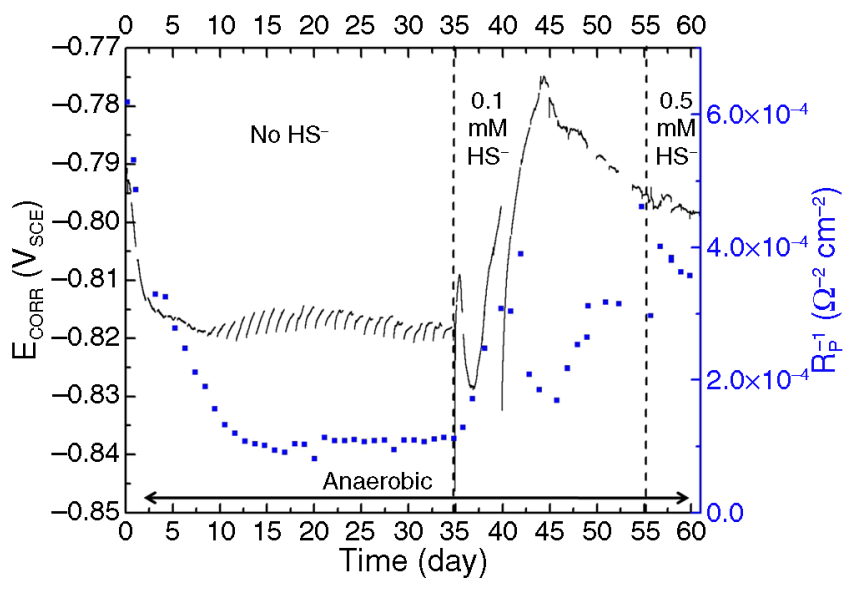

FIGURE 2. CE1: The change of corrosion potential $\left(E_{C O R R}\right.$, broken line) and inverse polarization resistance $\left(R_{P}^{-1}\right.$, proportional to the $C R$ [assuming uniform corrosion]; data dots) of untreated steel measured under anaerobic conditions. Aliquots of HS were added at various stages, and the labeled $\mathrm{HS}^{-}$concentration is that prevailing during a specific period. Noise in $E_{\text {CORR }}$ between 5 and 35 days is from electrochemical equipment and is $<5 \mathrm{mV}$ in amplitude. Electrical interference between days 38 and 39 resulted in a potential variance of $\sim 40 \mathrm{mV}$.

form a magnetite/siderite deposit; ${ }^{7}$ the values of both $\mathrm{E}_{\mathrm{CORR}}$ and $\mathrm{R}_{\mathrm{P}}^{-1}$ are typical for anaerobic corrosion. ${ }^{7-8}$

The addition of $1 \times 10^{-4} \mathrm{~mol} \mathrm{~L}^{-1} \mathrm{HS}^{-}$on day 35 led to an initial decrease in $\mathrm{E}_{\mathrm{CORR}}$ but eventually to a more substantial increase to $-775 \mathrm{mV}$ (35 to 45 days). These changes were accompanied by a peak in $\mathrm{R}_{\mathrm{P}}^{-1}$ ( 42 days). Beyond 45 days, a steady decrease in $\mathrm{E}_{\mathrm{CORR}}$ was accompanied by a corresponding increase in $\mathrm{R}_{\mathrm{P}}^{-1}$. The further addition of $\mathrm{HS}^{-}$, to a total concentration of $5 \times 10^{-4} \mathrm{~mol} \mathrm{~L}^{-1}$ (day 55) did not influence $\mathrm{E}_{\mathrm{CORR}}$ but led to an increase in $\mathrm{R}_{\mathrm{P}}^{-1}$ before a slight decrease over the period from 55 to 62 days. The variations in $\mathrm{E}_{\mathrm{CORR}}$ and $\mathrm{R}_{\mathrm{P}}^{-1}$ during the 6 to 7 days after $\mathrm{HS}^{-}$addition indicate an increased activation of the steel on exposure to sulfide. This behavior is similar to that observed on switching from anaerobic to aerobic corrosion..$^{9}$ Also, in both cases, the surface is subsequently partially repassivated by the formation of corrosion products. ${ }^{7-8}$ In the present case, the ongoing decrease in $\mathrm{E}_{\mathrm{CORR}}$ accompanied by an increase in $\mathrm{R}_{\mathrm{P}}^{-1}$ at times beyond 45 days indicates an overall activation of the surface corrosion process, as the anaerobically grown oxide is replaced by sulfide (refer to Figures 3 and 5 for comparison). The small influence of increasing [HS'] by a factor of 5 after 55 days indicates that the primary feature leading to the overall activation of the surface is not controlled by the absolute concentration of $\mathrm{HS}^{-}$, consistent with the suggestion that the changes in $\mathrm{R}_{\mathrm{P}}^{-1}$ are primarily attributable to changes in the properties of the corrosion product deposits.

Figures 3(a) and (b) show SEM micrographs of the steel surface after the anaerobic corrosion period (up to 35 days) but before $\mathrm{HS}^{-}$addition. Raman spectroscopy, Figure 4(a), identified the cubic crystals as siderite, $\mathrm{FeCO}_{3}\left(731 \mathrm{~cm}^{-1}\right.$ and $1,082 \mathrm{~cm}^{-1}$; vs. ref. $734 \mathrm{~cm}^{-1}$ and $\left.1,084 \mathrm{~cm}^{-1}\right),{ }^{18}$ and the layered crystal stacks as ferrous sulfate, $\mathrm{FeSO}_{4}\left(995 \mathrm{~cm}^{-1}\right.$; vs. ref. $\left.990 \mathrm{~cm}^{-1}\right) ;{ }^{20}$ the latter is presumed to have precipitated from solution during surface drying, since it is expected to be a soluble species. Figure 3(a) shows the base layer under the siderite and sulfate deposits to be thin and coherent at some locations but apparently porous at others. The high-magnification SEM image in Figure 3(b) shows this base layer to be ridged and covered with finely particulate material. Raman analysis yields a peak at $667 \mathrm{~cm}^{-1}$, suggesting that this thin layer may be magnetite (vs. ref. $666 \mathrm{~cm}^{-1}$ ), ${ }^{16}$ Figure 4(b). However, the sample fluoresces above $1,000 \mathrm{~cm}^{-1}$, as a result of electronic excitations of the underlying steel surface induced by the laser. The observed corrosion product deposits (i.e., siderite and magnetite) and $\mathrm{R}_{\mathrm{P}}^{-1}$ values (i.e., $<1 \times 10^{-4} \Omega^{-1} \mathrm{~cm}^{-2}$, Figure 2) are consistent with published observations on steel under anaerobic conditions. ${ }^{7,13}$

SEM micrographs (Figures 5[a] and [b]) show the film morphology at the end of the experiment (day 62) after exposure to $1 \times 10^{-4} \mathrm{~mol} \mathrm{~L}^{-1}$ and $5 \times 10^{-4} \mathrm{~mol} \mathrm{~L}^{-1}$ $\mathrm{HS}^{-}$solutions. The surface was uniformly covered by a "whiskery" corrosion product deposit with a fine porous structure. An EDX analysis, Figure 6(a), indicated that $\mathrm{S}, \mathrm{Fe}, \mathrm{O}, \mathrm{C}$, and $\mathrm{Na}$ were present on the surface. One possible source of silicon was the steel, which is known to contain Si $(0.26 \%)$. The strength of the S peak in the EDX spectrum compared to that for $O$ suggests that substantial amounts of iron sulfide are present.

Raman analysis of the film, Figure 6(b), reveals the presence of mackinawite identified by the peak at $315 \mathrm{~cm}^{-1}$ (vs. ref. $\left.318 \mathrm{~cm}^{-1}\right)^{17}$ and magnetite $\left(661 \mathrm{~cm}^{-1}\right.$ ), although unidentified peaks are also observed at $330 \mathrm{~cm}^{-1}$ and $366 \mathrm{~cm}^{-1}$. The broadening of the $661 \mathrm{~cm}^{-1}$ peak (vs. ref. $667 \mathrm{~cm}^{-1}$ ) ${ }^{16}$ for $\mathrm{Fe}_{3} \mathrm{O}_{4}$ could be because of its presence underneath a mackinawite layer. Surprisingly, Raman did not detect even a weak siderite signal at $\sim 1,082 \mathrm{~cm}^{-1}$. One possibility is that the siderite was covered with deposited sulfide. There is no reason to suspect that siderite reacted with $\mathrm{HS}^{-}$; in fact, Jack, et al., ${ }^{1}$ showed that siderite and mackinawite coexist under field conditions.

The dominance of mackinawite on the surface, but with residual magnetite, possibly in a sublayer, is consistent with the observed increase in $\mathrm{E}_{\mathrm{CORR}}$ and $\mathrm{R}_{\mathrm{P}}^{-1}$ (Figure 2). The increase in these parameters on the first addition of $\mathrm{HS}^{-}$is not unexpected based on the observation that the $\mathrm{Fe}_{3} \mathrm{O}_{4}$ base layer is porous prior to $\mathrm{HS}^{-}$addition (Figure $3[\mathrm{~b}]$ ) and hence susceptible to accelerated active corrosion. The subsequent increase in $\mathrm{E}_{\mathrm{CORR}}$ and decrease in $\mathrm{R}_{\mathrm{P}}^{-1}$ (40 to 45 days, Figure 2) suggests that the mackinawite layer is initially partially passivating. However, this state is tem- 


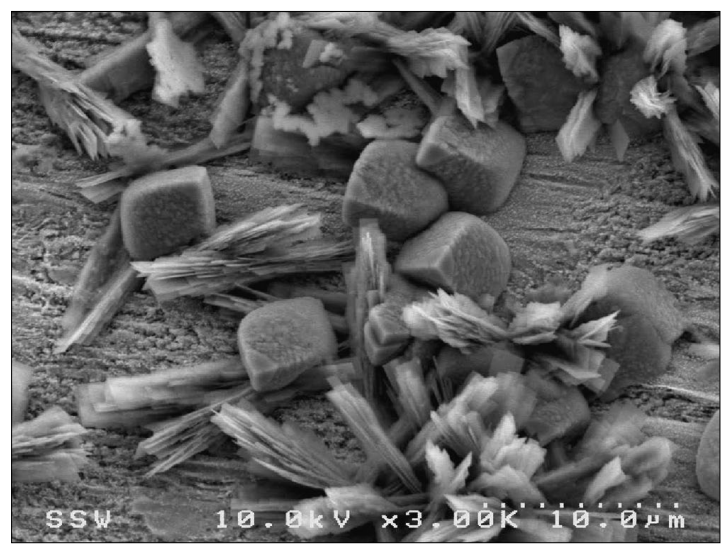

(a)

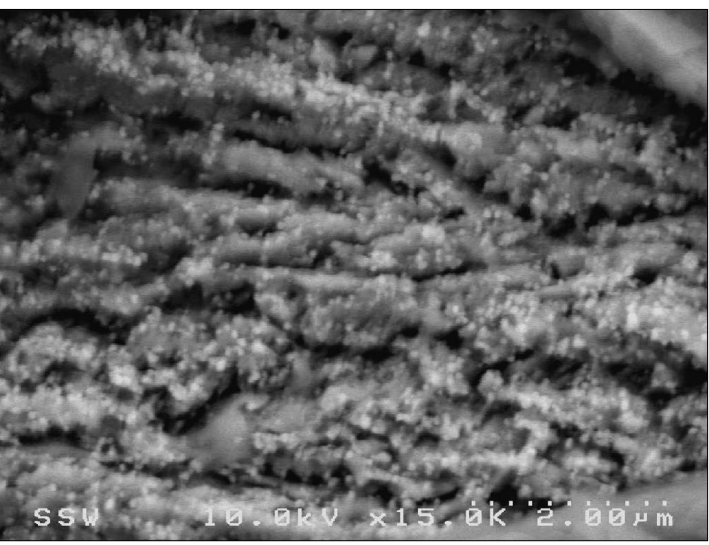

(b)

FIGURE 3. CE1: (a) SEM micrographs of an anaerobically corroded steel surface before $\mathrm{HS}^{-}$addition on day 35; (b) a close up of the base layer in (a).

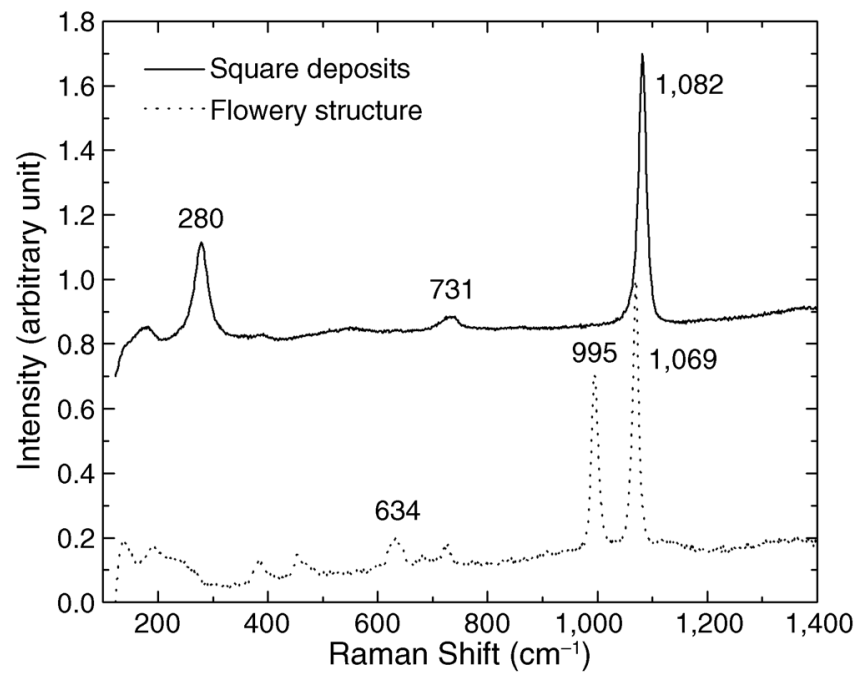

(a)

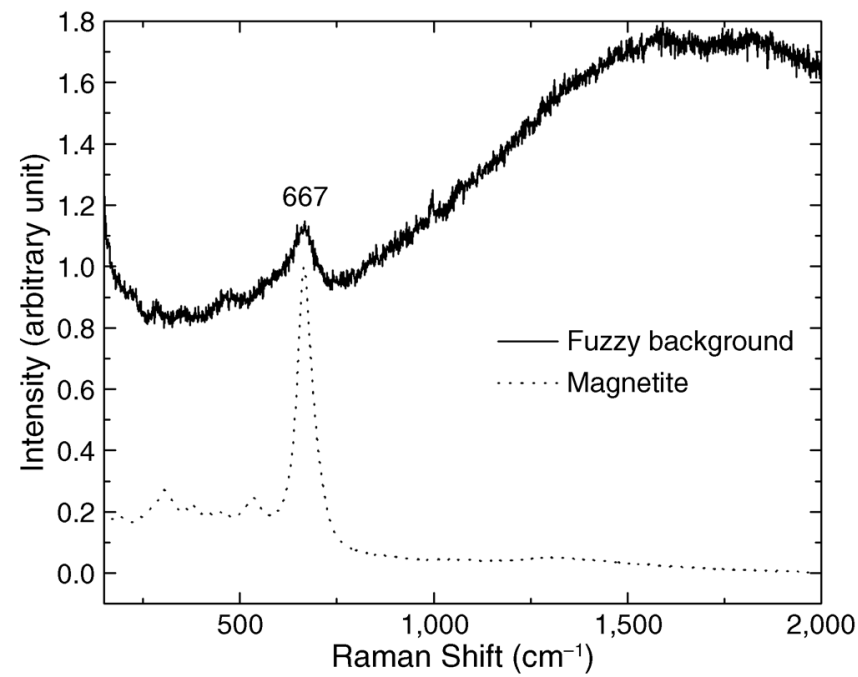

(b)

FIGURE 4. CE1: Raman spectra recorded on anaerobically corroded steel before the addition of HS (35 days). Spectra recorded on (a) the cubic crystals shown in Figure 3(a), and (b) the base layer shown in Figure 3(b). Also shown in (b) is a reference spectrum for magnetite.

porary, and passivity is not maintained, as indicated by the long-term trend in $\mathrm{E}_{\mathrm{CORR}}$ (from $-780 \mathrm{mV}$ to $-800 \mathrm{mV}$ ) accompanied by an increasing $\mathrm{R}_{\mathrm{P}}^{-1}$. This long-term increase in $\mathrm{R}_{\mathrm{P}}^{-1}$ and the accumulation of mackinawite at the film-solution interface indicates the ongoing transport of $\mathrm{Fe}^{2+}$ out of the pores in the magnetite sublayer. This observation is consistent with the mechanism claimed by Newman, et al., ${ }^{5}$ that consumption of $\mathrm{HS}^{-}$at the outer film surface leads to its depletion at the metal interface at the base of pores and, hence, the maintenance of the pore structure. The persistence of $\mathrm{Fe}_{3} \mathrm{O}_{4}$ on the surface is also not unexpected since Poulton, et al., ${ }^{22}$ have shown that the direct reaction of magnetite with $\mathrm{HS}^{-}$is slow on the time scale of this experiment. In addition, at the prevailing negative $\mathrm{E}_{\mathrm{CORR}}$ values, it is possible that the corrosion process could be sustained by proton reduction on the outer $\mathrm{Fe}_{3} \mathrm{O}_{4}$ and $\mathrm{Fe}_{1+\mathrm{x}} \mathrm{S}$ surfaces, which should occur below $-772 \mathrm{mV}$, at $\mathrm{pH} 9$. If the cathodic reaction were to be separated spatially from the anodic reaction in this manner, then the sulfide-depleted locations at the base of the pores could become slightly acidified by $\mathrm{Fe}^{2+}$ hydrolysis.

The $\mathrm{E}_{\mathrm{CORR}}$ and $\mathrm{R}_{\mathrm{P}}^{-1}$ behaviors suggest that anaerobic corrosion of the magnetite/siderite-covered surface proceeds in stages after the addition of $\mathrm{HS}^{-}$. The initial increase in these two parameters suggests that $\mathrm{HS}^{-}$accelerates corrosion within pores in the surface deposits. Since the solution contains a large inventory of $\mathrm{H}^{+}$stored in the $\mathrm{HCO}_{3}^{-} / \mathrm{CO}_{3}^{2-}$ buffer, it is likely that this acceleration is driven by proton reduction on the outer surfaces of the magnetite deposit. ${ }^{7}$ Transport of dissolved $\mathrm{Fe}^{2+}$ out of the pores would initiate the general deposition of mackinawite across the surface, 


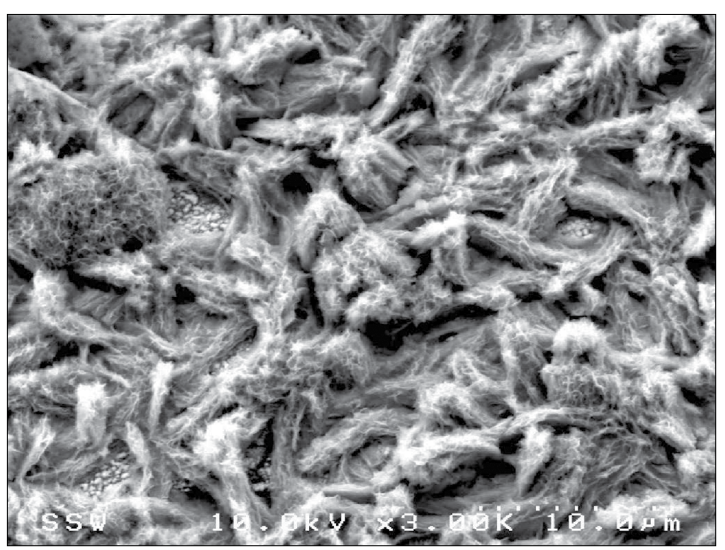

(a)

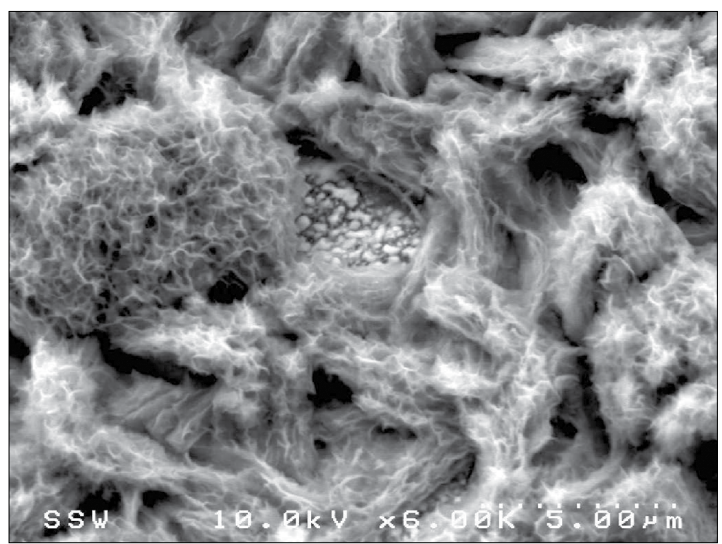

(b)

FIGURE 5. CE1: (a) Low- and (b) high-magnification SEM micrographs recorded on an anaerobically corroded steel surface after 61 days of exposure, the final 26 days with sulfide present.

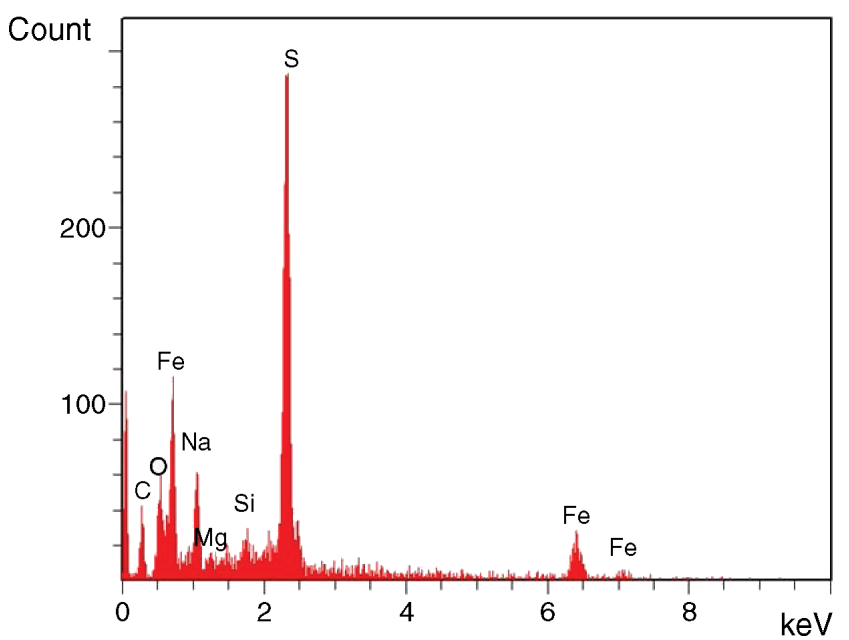

(a)

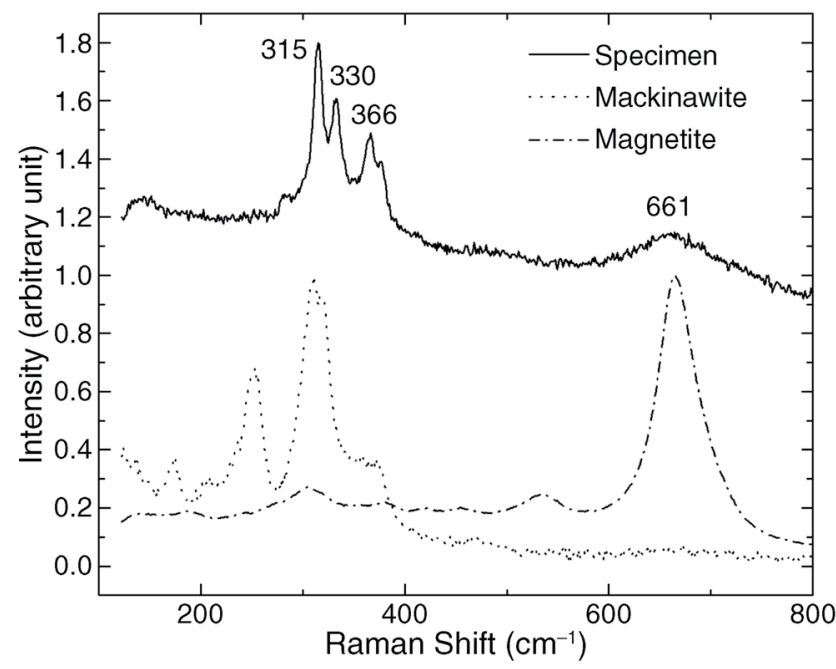

(b)

FIGURE 6. CE1: (a) an EDX spectrum and (b) Raman spectra recorded on the surface shown in Figure 5. Also shown in (b) are reference spectra for magnetite and mackinawite.

as indicated by the SEM/EDX and Raman analyses. Hansson, et al., ${ }^{23}$ also proposed that $\mathrm{Fe}^{2+}$ could diffuse out of porous magnetite films and react with $\mathrm{HS}^{-}$to form mackinawite at the mouth of pores. A schematic illustration of this process is shown in Figure 7(a). With time, however, the eventual accumulation of mackinawite within the pores leads to blockage of the corrosion process, Figure 7 (b), which would account for the decrease in $\mathrm{R}_{\mathrm{P}}^{-1}$.

The steady increase in $\mathrm{R}_{\mathrm{P}}^{-1}$ and decrease in $\mathrm{E}_{\mathrm{CORR}}$ at longer exposure times ( $>45$ days, Figure 2 ) suggest a further replacement of the magnetite by porous and less protective mackinawite. It is well established that $\mathrm{HS}^{-}$can reduce oxy-hydroxides and oxides, including magnetite, by a surface process. ${ }^{22}$ Under the acidicto-neutral conditions likely in the pores of deposits, magnetite can be dissolved slowly and reductively by reaction with $\mathrm{HS}^{-}$:

$$
\mathrm{Fe}_{3} \mathrm{O}_{4}+4 \mathrm{HS}^{-}+4 \mathrm{H}^{+} \rightarrow 3 \mathrm{FeS}+\mathrm{S}^{0}+4 \mathrm{H}_{2} \mathrm{O}
$$

Such a reaction could account for the slow decrease in $\mathrm{E}_{\mathrm{CORR}}$ and increase in $\mathrm{R}_{\mathrm{P}}^{-1}$ for exposure times longer than 45 days (Figure 2). Since no $\mathrm{S}^{0}$ was detected by Raman spectroscopy, the occurrence of this reaction cannot be confirmed. The relative insensitivity of $\mathrm{R}_{\mathrm{P}}^{-1}$ to a five-fold increase in [HS-] indicates that the rate of this oxide-to-sulfide conversion process is controlled by slow surface kinetics and, hence, effectively independent of [HS ${ }^{-}$. Based on thermodynamics ${ }^{24}$ and field observations, ${ }^{1,4}$ siderite would be expected to remain unaffected by the presence of $\mathrm{HS}^{-}$.

\section{CE2: Effect of Sulfide on Steel with No Anaerobically Formed Oxide/Carbonate Layer}

In this experiment, one freshly polished steel electrode was exposed to a solution containing anion con- 
centrations more representative of those anticipated on pipelines. A key difference between this solution and that used in $\mathrm{CE} 1$ is the much lower $\mathrm{HCO}_{3}^{-} / \mathrm{CO}_{3}^{2-}$ concentration, Table 1 . In principle, this will limit the availability of protons, supplied by $\mathrm{HCO}_{3}^{-}$dissociation, able to support corrosion. A second difference is the presence of $\mathrm{HS}^{-}$from the beginning of the experiment. According to Newman, et al., ${ }^{5}$ passivating sulfide films would be expected in the absence of any pre-corrosion of the steel.

Figure 8 shows the changes in $\mathrm{E}_{\mathrm{CORR}}$ and $\mathrm{R}_{\mathrm{P}}^{-1}$ recorded over the 78 day duration of the experiment. Overall, $\mathrm{E}_{\mathrm{CORR}}$ was significantly lower, by up to $80 \mathrm{mV}$, than the values recorded under anaerobic conditions in the absence of $\mathrm{HS}^{-}$(CE1, up to 35 days). Over the course of the experiment $\mathrm{E}_{\mathrm{CORR}}$ exhibited a series of rises (from $\sim-900 \mathrm{mV}$ to $\sim-830 \mathrm{mV}$ ) followed by periodic decreases to values close to the initial value. Despite these sudden changes, only a small change in $\mathrm{R}_{\mathrm{P}}^{-1}$ was observed: its value approximately doubles, from $2.5 \times 10^{-5} \Omega^{-1} \mathrm{~cm}^{-2}$ to $5.0 \times 10^{-5} \Omega^{-1} \mathrm{~cm}^{-2}$, over the duration of the experiment. Additionally, periodic increases in $\left[\mathrm{HS}^{-}\right]$did not cause noticeable changes in either $\mathrm{E}_{\mathrm{CORR}}$ or $\mathrm{R}_{\mathrm{P}}^{-1}$, and overall a nine-fold increase in [HS ${ }^{-}$was accompanied by only a doubling in $\mathrm{R}_{\mathrm{P}}^{-1}$. The mean value of $\mathrm{R}_{\mathrm{P}}^{-1}$ in the presence of sulfide is $4.5 \pm$ $0.6 \times 10^{-5} \Omega^{-1} \mathrm{~cm}^{-2}$, which is effectively the same as the value recorded under anaerobic conditions in the absence of sulfide $\left(4.4 \pm 1.2 \times 10^{-5} \Omega^{-1} \mathrm{~cm}^{-2}\right){ }^{7}$

Figure 9(a) shows a low-resolution SEM micrograph depicting the uniform morphology of the corroded surface after 44 days. The visibility of the polishing lines demonstrates that the surface film was thin, as expected for the low $\mathrm{R}_{\mathrm{P}}^{-1}$ values measured (i.e., $4.5 \pm 0.6 \times 10^{-5} \Omega^{-1} \mathrm{~cm}^{-2}$ ). The high-resolution image in Figure 9(b) suggests that the film was porous. Raman analysis shows the film was predominantly mackinawite $\left(250,308\right.$, and $\left.351 \mathrm{~cm}^{-1}\right)$ and sulfur ( 217 and $474 \mathrm{~cm}^{-1}$; vs. ref. 220 and $\left.475 \mathrm{~cm}^{-1}\right),{ }^{22}$ Figure 9(c). The very broad peak with a maximum between $600 \mathrm{~cm}^{-1}$ and $700 \mathrm{~cm}^{-1}$ suggests the presence of magnetite $\left(666 \mathrm{~cm}^{-1}\right)$; possibly as a film on the steel surface beneath the outer mackinawite layer. While this analysis shows mackinawite to be the dominant corrosion product, the identification of $\mathrm{S}^{0}$ adds credibility to the claim that magnetite is present, since $\mathrm{S}^{0}$ formation would be expected via the conversion process, Reaction (1). There appear to be two possible reasons for the low corrosion rate:

-the magnetite/mackinawite film is compact and protective;

- the low concentration of stored protons (as $\mathrm{HCO}_{3}^{-}$) limits the rate of the cathodic reaction.

\section{CE3: Effect of Sulfide on Carbon Steel Covered by a Thick Oxide Corrosion Product Layer}

Figure 10 shows $\mathrm{E}_{\mathrm{CORR}}$ and $\mathrm{R}_{\mathrm{P}}{ }^{-1}$ values recorded over the last two anaerobic sections of a long experi-

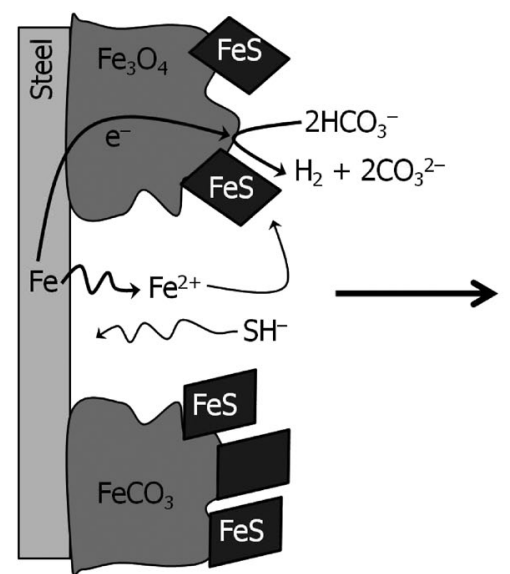

(a)

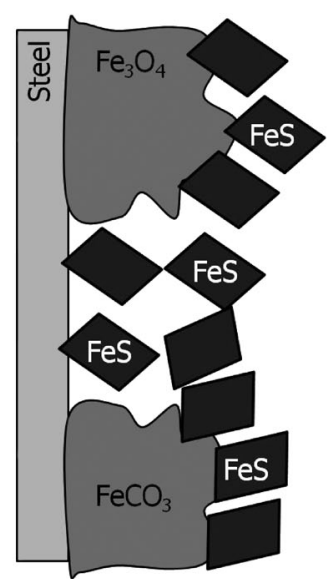

(b)
FIGURE 7. Schematic illustrating (a) sulfide-accelerated steel corrosion in pores in the siderite/magnetite film and (b) partial passivation of the pores by the accumulation of mackinawite.

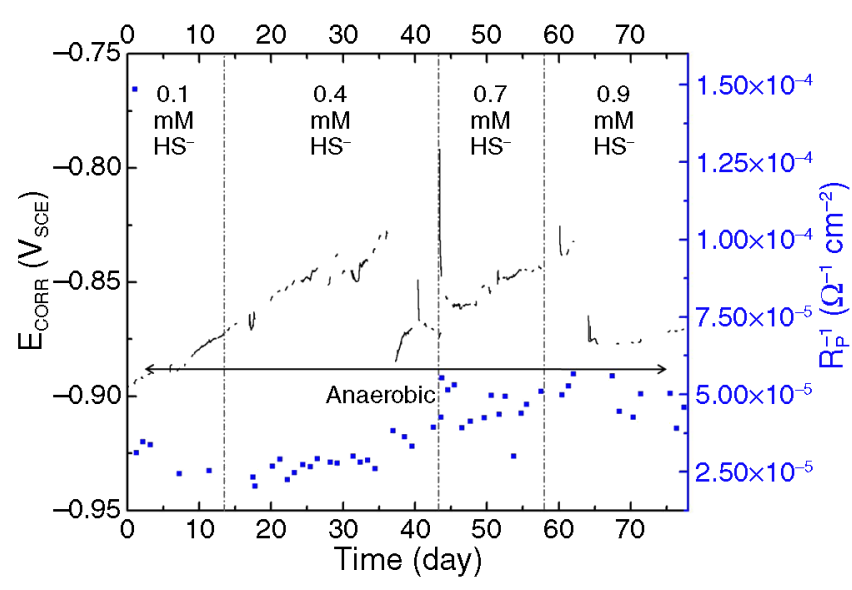

FIGURE 8. CE2: Corrosion potential ( $E_{\text {CORR }}$, broken line) and inverse polarization resistances $\left(R_{P}^{-1}\right.$, data dots) recorded on steel exposed to anaerobic conditions in a solution containing sulfide. Aliquots of $\mathrm{HS}^{-}$were added at various times and the labeled $\mathrm{HS}^{-}$concentration is cumulative for a specific period.

ment involving a series of anaerobic-aerobic cycles over the first 202 days (CE3). The behavior observed through these cycles has been described in detail elsewhere. $^{8-9}$ By the time sulfide was added (202 days, Figure 10), a portion of the surface was covered by an orange tubercle ( $\sim \mathrm{mm}$ to $4 \mathrm{~mm}$ in cross section), beneath which the steel was pitted to a depth of $\sim 275 \mu \mathrm{m}$. However, the majority of the surface was uniformly corroded and covered with a black, compact magnetite $\left(\mathrm{Fe}_{3} \mathrm{O}_{4}\right) /$ maghemite $\left(\gamma-\mathrm{Fe}_{2} \mathrm{O}_{3}\right)$-dominated film $\left(\sim 4.5 \mu \mathrm{m}\right.$ thick). ${ }^{8}$ Despite the variations in $\mathrm{E}_{\mathrm{CORR}}$ over the final anaerobic period prior to $\mathrm{HS}^{-}$addition (140 to 202 days, Figure 10), $\mathrm{R}_{\mathrm{P}}^{-1}$ showed only minor fluctuations, which is consistent with the conclusions drawn previously, ${ }^{8}$ that corrosion was concentrated within the tubercle-covered site ${ }^{9}$ and that the surface beneath the thick oxide film was largely protected and 


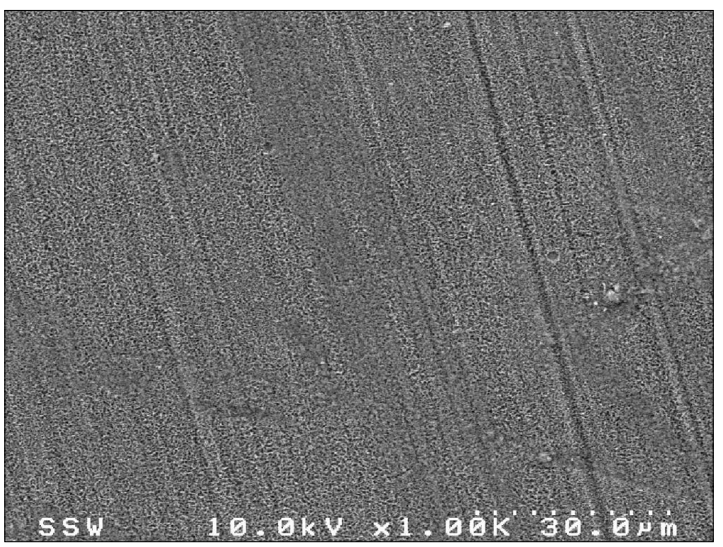

(a)

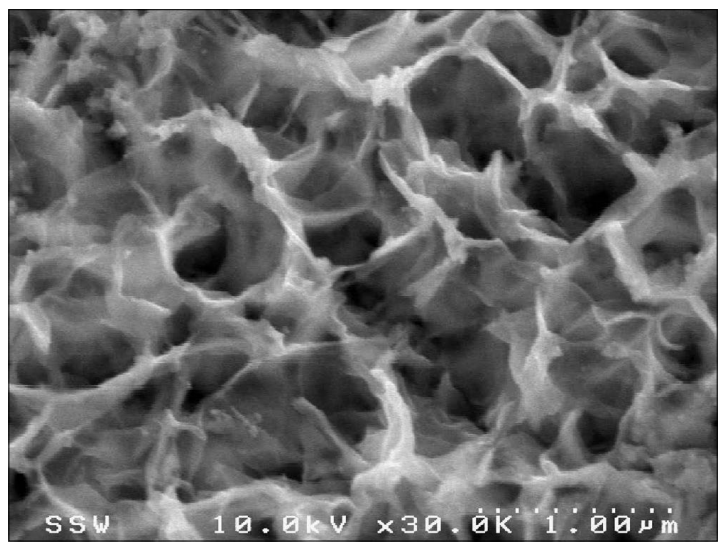

(b)

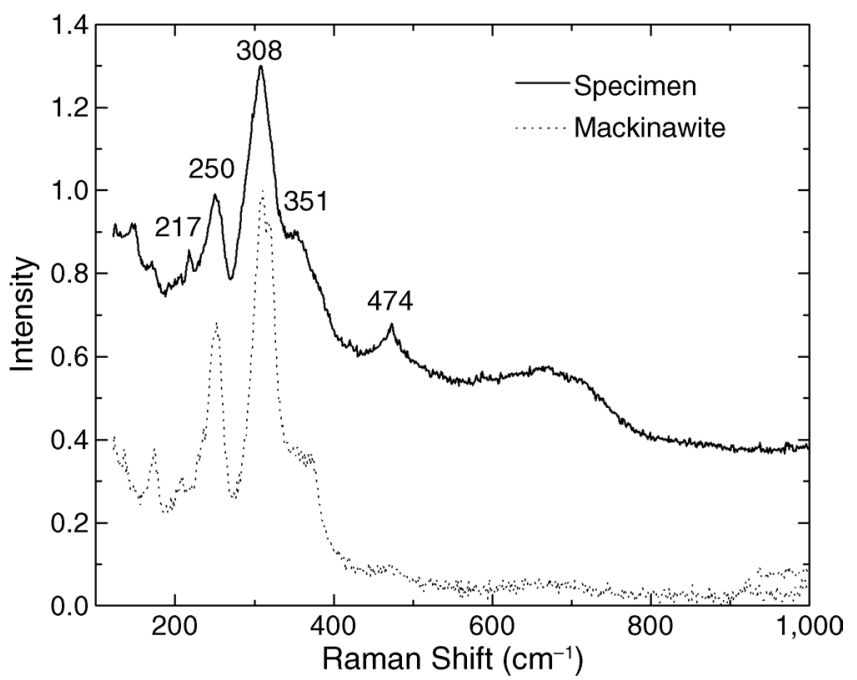

(c)

FIGURE 9. CE2: $(a, b)$ SEM micrographs of a steel surface after anaerobic corrosion in a sulfide-containing solution for 44 days and (c) a Raman spectrum recorded on the same area. $A$ reference spectrum for mackinawite is also shown.

inert. ${ }^{8}$ Consequently, added sulfide does not gain access to the active steel surface under the tubercle.

$\mathrm{EDX}^{8}$ and back-scattered electron (BSE) analyses, Figure 11, performed on termination of the experiment after 238 days detected nano-sized S-containing

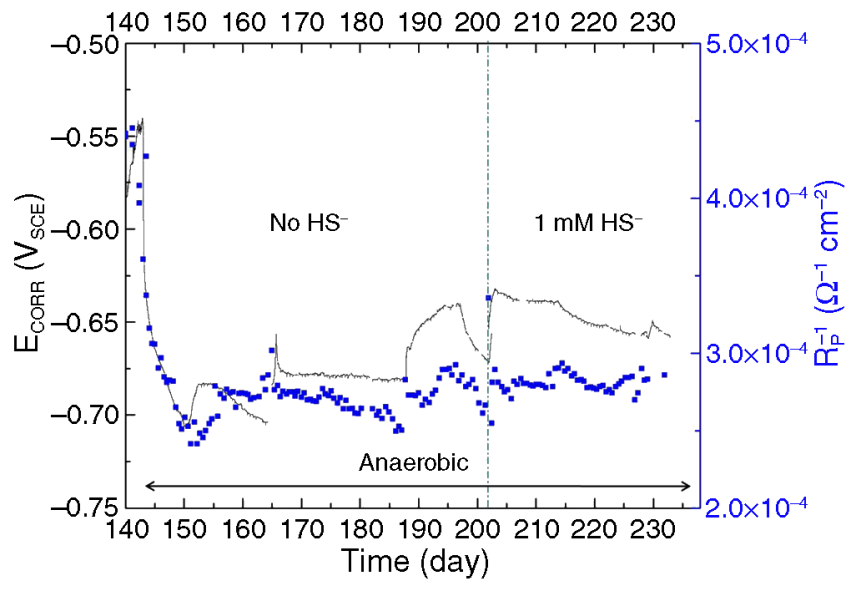

FIGURE 10. CE3: The change of corrosion potential ( $E_{\text {CORR }}$, broken line) and inverse polarization resistance $\left(R_{P}^{-1}\right.$, data dots) measured during the final anaerobic period after a series of alternating anaerobic-aerobic cycles in CE3. Details regarding the corrosion behavior before day 140 can be found elsewhere. ${ }^{8-9}$ On day 202, $1 \times$ $10^{-3} \mathrm{~mol} \mathrm{~L}^{-1} \mathrm{HS}^{-}$was added to the exposure solution.

particles, presumed to be mackinawite, on the outer surface of the oxide. However, SEM/EDX analysis of cross sections of the $\sim 4.5 \mu \mathrm{m}$ oxide, prepared using focused ion beam milling, revealed no penetration of $\mathrm{HS}^{-}$through pores in the oxide. ${ }^{8}$ The minor surface sulfide deposits indicated a very slow reaction of $\mathrm{HS}^{-}$ with the maghemite-covered surface, as expected from the results of Poulton, et al., ${ }^{22}$ indicating that such an oxide-to-sulfide conversion reaction would be slow.

\section{Anaerobic Corrosion Rates in the Presence of Sulfide}

The $\mathrm{R}_{\mathrm{P}}^{-1}$ values calculated for the various phases in each experiment are plotted in Figure 12. The error bars in this figure illustrate one half the standard error associated with the calculated mean values. The calculated $\mathrm{R}_{\mathrm{P}}^{-1}$ values, and the exposure intervals over which they were calculated, are shown in Table 4. The term "pre-transition" refers to $R_{P}^{-1}$ values measured under anaerobic conditions while $\mathrm{E}_{\mathrm{CORR}}$ was $<-800 \mathrm{mV}$ and "post-transition" to values measured under anaerobic conditions after $\mathrm{E}_{\mathrm{CORR}}$ has undergone a transition to a value of $>-550 \mathrm{mV}$.

In all the experiments described here (where corrosion is effectively uniform), these values can be taken as relative CR. In this study, a thorough Tafel analysis was not performed on carbon steel exposed to sulfide. As the Tafel slopes are expected to change depending upon the concentration of sulfide exposed to the steel, no attempt is made to quantify a "real" CR that could be applied to a predictive model. Nevertheless, comparison of the relative CR measured in $\mathrm{CE} 1$ and CE2 clearly demonstrate that the corrosion behavior is influenced by the corrosion history of the steel prior to the addition of $\mathrm{HS}^{-}$. When the steel has been subjected to a period of anaerobic corro- 


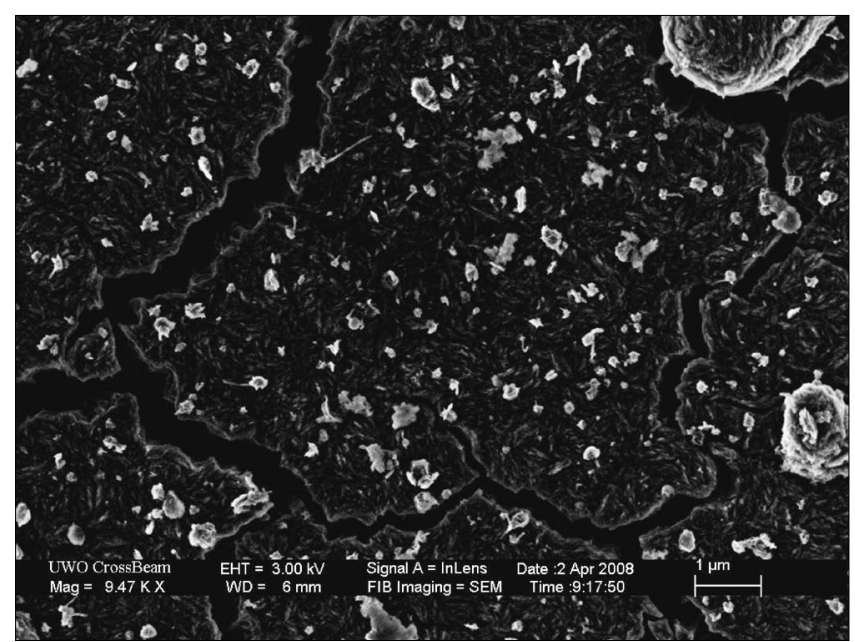

FIGURE 11. CE3: BSE micrographs of the compact black surface layer covering the majority of the steel surface after 238 days of exposure. EDX analysis detected $S$ in the small, submicron white particles.

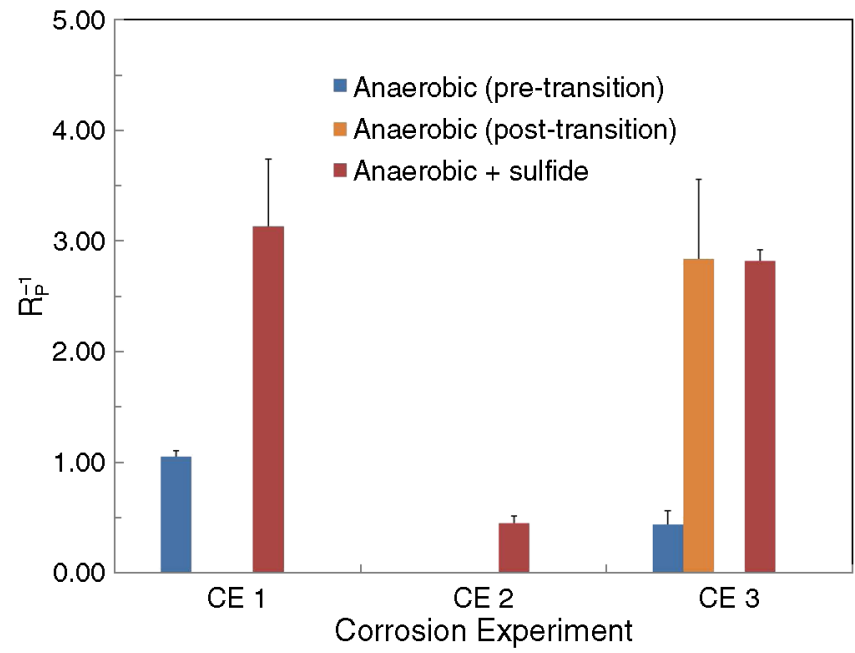

FIGURE 12. Comparison of relative anaerobic $R_{P}^{-1}$ values for individual corrosion experiments calculated over specified intervals. $R_{P}^{-1}$ values were calculated as described in Table 4.

TABLE 4

Summary of Calculated $R_{P}^{-1}$ Values (Proportional to Corrosion Rate) for Individual Experiments Under Specific Exposure Conditions

\begin{tabular}{|c|c|c|c|}
\hline $\begin{array}{l}\text { Corrosion } \\
\text { Experiment }\end{array}$ & Exposure Conditions & $\begin{array}{l}\text { Period Over Which the } \\
\text { Rate was Calculated }\end{array}$ & $\begin{array}{l}\text { Average Rate/ } \\
10^{-4} \Omega^{-1} \mathrm{~cm}^{-2}\end{array}$ \\
\hline CE1 & $\begin{array}{l}\text { (i) Anaerobic (pre-transition) } \\
\text { (ii) Anaerobic (with } \mathrm{HS}^{-} \text {) }\end{array}$ & $\begin{array}{l}10 \text { to } 35 \text { days (Figure 2) } \\
35 \text { to } 60 \text { days (Figure 2) }\end{array}$ & $\begin{array}{l}1.05 \pm 0.06 \\
3.13 \pm 0.61\end{array}$ \\
\hline CE2 & (i) Anaerobic (with $\mathrm{HS}^{-}$) & 0 to 79 days (Figure 8 ) & $0.45 \pm 0.06$ \\
\hline CE3 & $\begin{array}{l}\text { (i) Anaerobic (pre-transition) } \\
\text { (ii) Anaerobic (post-transition) } \\
\text { (iii) Anaerobic (with } \mathrm{HS}^{-} \text {) }\end{array}$ & $\begin{array}{l}0 \text { to } 25 \text { days }^{7} \\
25 \text { to } 45 \text { days }^{8} \\
202 \text { to } 238 \text { days (Figure 10) }\end{array}$ & $\begin{array}{l}0.44 \pm 0.12 \\
3.09 \pm 0.27 \\
2.82 \pm 0.10\end{array}$ \\
\hline
\end{tabular}

sion prior to $\mathrm{HS}^{-}$addition (CE1), the rate is increased substantially by $\mathrm{HS}^{-}$addition and is dependent on [HS ${ }^{-}$, Figure 2 . The rate obtained in CE2 is effectively the same as the anaerobic rate obtained in the early stages of CE3, measured with a preformed magnetite/ siderite layer present in the absence of $\mathrm{HS}^{-8-9}$ This suggests that the $\mathrm{CR}$ is controlled by the properties of the corrosion product film, irrespective of whether this is magnetite/siderite (CE3) or mackinawite (CE2). An additional difference between experiments CE2 and $\mathrm{CE} 3$ is the $\mathrm{HCO}_{3}^{-} / \mathrm{CO}_{3}^{2-}$ concentration, which is high in CE3 and low in CE2 (Table 2). As discussed above, a high concentration provides a large inventory of protons that potentially can support the cathodic corrosion reaction. The similar CR in CE2 and in CE3 under early anaerobic conditions in the absence of $\mathrm{HS}^{-}$indicate, therefore, that the corrosion process is not cathodically controlled, consistent with our claim that the CR is anodically controlled by the properties of the surface deposits.

In experiment $\mathrm{CE} 1$, which was also performed in a solution containing a high $\mathrm{HCO}_{3}^{-} / \mathrm{CO}_{3}^{2-}$, the addi- tion of $\mathrm{HS}^{-}$increases the CR considerably, despite an attempt to repassivate, over 26 days, Figure 2 . As discussed above, and illustrated schematically in Figure 13, this increased CR can be attributed to the ability of $\mathrm{HS}^{-}$to accelerate corrosion initially in pores in the preformed magnetite/siderite layer. Since sulfide formation does not passivate the surface, in this case, control of the overall CR by the corrosion product deposit is destroyed. It is possible, but presently unproven, that the enhanced anodic demand is provided by $\mathrm{H}^{+}$reduction on conducting magnetite and mackinawite surfaces. The dependence on sulfide concentration then could be explained as from a rebalancing of anodic and cathodic kinetics since conducting magnetite deposits are converted to mackinawite by reaction with $\mathrm{HS}^{-}$via Reaction (1).

\section{CONCLUSIONS}

The influence of sulfide on the anaerobic corrosion of carbon steel has been studied in a range of conditions: 


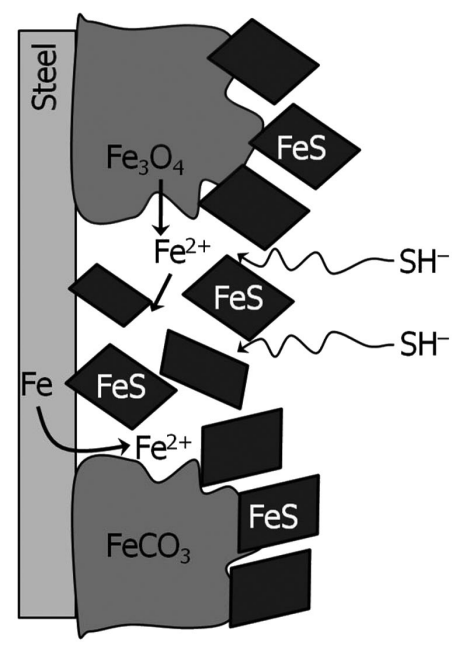

FIGURE 13. Schematic illustration of the reaction of sulfide with a precorroded steel surface under anaerobic conditions.

* When sulfide is present from the beginning of steel exposure to aqueous solution, a layer of mackinawite is formed. The $\mathrm{CR}$ is independent of $\left[\mathrm{HS}^{-}\right]$, indicating that the rate is controlled by the properties of the sulfide film in dilute simulated ground waters.

* If the steel has undergone a period of anaerobic corrosion leading to the formation of a magnetite/siderite film, the addition of sulfide causes an increase in the CR initially within pores in the film. However, the mackinawite deposit that has formed does not passivate the surface and the chemical conversion of magnetite by reaction with $\mathrm{HS}^{-}$to form mackinawite leads to a steady ongoing increase in CR. Therefore, corrosion appears to be sustained by proton reduction on magnetite/mackinawite surfaces when the $\left[\mathrm{HCO}_{3}^{-}\right]$ is high.

* When a thick magnetite/maghemite film is present, as a consequence of a sequence of anaerobic-aerobic corrosion cycles, the addition of sulfide has no immediate effect on the CR. The presence of small amounts of mackinawite on the oxide surface implies minor chemical conversion of the thick film, suggesting that CR could increase eventually.

\section{ACKNOWLEDGMENTS}

This research was carried out for NOVA Research and Technology Centre (NRTC, Calgary, AB, Canada) and TCPL through an Industrial Postgraduate Scholarship Agreement with the University of Western Ontario and the Canadian Natural Sciences and Engineering Research Council (NSERC, Ottawa, ON, Canada). F. King, Integrity Corrosion Consulting Ltd., is gratefully acknowledged by the authors for his guidance and continued support of the research.

\section{REFERENCES}

1. T.R. Jack, M.J. Wilmott, R.L. Sutherby, Mater. Perform. 34, 11 (1995): p. 19.

2. T.R. Jack, M.J. Wilmott, R.L. Sutherby, R.G. Worthingham, Mater. Perform. 35, 3 (1996): p. 18.

3. T.R. Jack, A. Wilmott, J. Stockdale, G. Van Boven, R.G. Worthingham, R.L. Sutherby, Corrosion 54, 3 (1998): p. 246, doi: http://dx.doi.org/10.5006/1.3284850.

4. R.G. Worthingham, T.R. Jack, V. Ward, "External Corrosion of Line Pipe-Part I: Indentification of Bacterial Corrosion in the Field," in Biologically Induced Corrosion, ed. S.C. Dexter (Houston, TX: NACE International, 1986).

5. R.C. Newman, K. Rumash, B.J. Webster, Corros. Sci. 33, 12 (1992): p. 1877.

6. B.W.A. Sherar, I.M. Power, P.G. Keech, S. Mitlin, G. Southam, D.W. Shoesmith, Corros. Sci. 53, 3 (2011): p. 955.

7. B.W.A. Sherar, P.G. Keech, Z. Qin, F. King, D.W. Shoesmith, Corrosion 66, 4 (2010): p. 045001, doi: http://dx.doi.org/10.5006/ 1.3381566 .

8. B.W.A. Sherar, P.G. Keech, D.W. Shoesmith, Corros. Sci. 53, 11 (2011): p. 3636.

9. B.W.A. Sherar, P.G. Keech, D.W. Shoesmith, Corros. Sci. 53, 11 (2011): p. 3643.

10. T.R. Jack, G. Vanboven, M. Wilmott, R.L. Sutherby, R.G. Worthingham, Mater. Perform. 33, 8 (1994): p. 17.

11. A.M. Moore, C.H. De Leon, T.M. Young, Environ. Sci. Technol. 37, 14 (2003): p. 3189.

12. Z. Qin, B. Demko, J.J. Noël, D.W. Shoesmith, F. King, R.G. Worthingham, K. Keith, Corrosion 60, 10 (2004): p. 906, doi: http://dx.doi.org/10.5006/1.3287824.

13. C.T. Lee, Z. Qin, M. Odziemkowski, D.W. Shoesmith, Electrochim. Acta 51, 8-9 (2006): p. 1558.

14. C.T. Lee, M.S. Odziemkowski, D.W. Shoesmith, J. Electrochem. Soc. 153, 2 (2006): p. B33.

15. C.T. Lee, "The Corrosion of Carbon Steel Within a Failed Canadian Nuclear Waste Container" (Ph.D. diss., The University of Western Ontario, 2006).

16. M.A. Legodi, D. de Waal, Dyes Pigm. 74, 1 (2007): p. 161.

17. M. Langumier, R. Sabot, R. Obame-Ndong, M. Jeannin, S. Sablé, Ph. Refait, Corros. Sci. 51, 11 (2009): p. 2694.

18. R.G. Herman, C.E. Bogdan, A.J. Sommer, D.R. Simpson, Appl. Spectrosc. 41, 3 (1987): p. 437.

19. J.A. Bourdoiseau, M. Jeannin, R. Sabot, C. Remazeilles, P. Refait, Corros. Sci. 50, 11 (2008): p. 3247.

20. C.H. Chio, S.K. Sharma, D.W. Muenow, Spectrochim. Acta, Part A 61,10 (2005): p. 2428.

21. S.N. White, Chem. Geol. 259, 3-4 (2009): p. 240.

22. S.W. Poulton, M.D. Krom, R. Raiswell, Geochim. Cosmochim. Acta 68, 18 (2004): p. 3703.

23. E.B. Hansson, M.S. Odziemkowski, R.W. Gillham, Corros. Sci. 48 , 11 (2006): p. 3767.

24. N. Sridhar, D.S. Dunn, A.M. Anderko, M.M. Lencka, U. Schutt, Corrosion 57, 3 (2001): p. 221, doi: http://dx.doi. org/10.5006/1.3290347. 